\title{
The Perspectives of Natural Adaptogenes Application in Sports
}

\author{
Kasyanov GI*, Khristuk AV, Grinchenko VS and Mazurenko EA \\ Kuban State Technological University, Russia \\ Submission: February 23, 2017; Published: April 26, 2017 \\ *Corresponding author: Kasyanov GI, Kuban State Technological University, Krasnodar, Russia, Email: g_kasjanov@mail.ru
}

\begin{abstract}
The problem of choice and application of natural adaptogenes to increase athletes' stamina and endurance is formulated. Now the word "doping" is often used, when one speaks about sport of high achievements. Many professional athletes and sports amateurs are tempted to take stimulating food additives together with food to achieve better results. Lately some extraordinary measures have been taken to prevent spreading of this evil in the sports world. The aim of this research was the survey of scientific papers devoted to the application of medicinal plants which may help an athlete to cope with a lot of physical tension which an athlete experiences during training sessions and competitions. Inadequate rest does not give a possibility to get rehabilitated before the competition, to reach the desired level of preparation and to achieve high results. Aponic additives increase natural body resources. Today to take additives increasing endurance becomes fashionable even for ordinary people, when they experience high workload and pressures. The negative sides of getting adaptogenes at the moment are ethanol used as a solvent and a high temperature used to prepare a certain plant brew. The authors offered to use liquid CO2 to extract adaptogenes from vegetative raw materials.
\end{abstract}

Keywords: Muscles workload; Adaptation; Adaptogenes; $\mathrm{CO}_{2}$-extracts; Anthropometric information; Muscles power; Stamina (endurance); Medicinal plant; External medium

\section{Mini Review}

The development of modern sport goes hand in hand with the increase of a training process amount and its intensity which exercises pressure on an adaptive potential of an athlete. To achieve certain levels as a result of these training sessions and the desired rehabilitation, it is necessary to sophisticate the management of physiological and biochemical processes of an athlete.

This fully explains an increased interest for an application of certain means of normalization and acceleration of rehabilitation process of a non-doping character. Intensive sport sessions and high physical load require a set of special food products to accompany them [1-4].

At present many specialized food products producers and a lot of athletes pay attention to studying special properties and application of medicinal plants [5-7]. Some plants from a diversity of varieties are especially well-known. The main dominating feature of these plants group is a strong general health-improving function, a tonus increase, a performance, stamina and immunity increase, a rise in resistance to some unfavourable natural factors and pathogenic microbes. The plants which strengthen sportsmen's health are called "adaptogenes".

If one finds the mechanism of skilful adaptogens' strength release, it will be possible to prevent many illnesses, as well as to increase a level of sports achievements. However, up till now the ways of application, pharmacological efficiency and dosages of phytoadaptogens into prophylactic foodstuffs are not completely studied [8-10].

The best vegetative adaptogenes grow on the territory of Russia in wild nature. The term "adaptogene" was introduced by a Soviet scientist Nikolay Lazarev [11,12].

One of the most well-known and almost legendary plant --adaptogenes is a gingseng root, but it does not possess the strongest characteristics.

The following plants are also rather powerful as adaptogenes: hypericum, leuzea, eleutherococcus, Schisandra.

The role of adaptogenes lies in adaptation of an organismus to some un favourable factors of external environment-cold, heat, ionizing radiation, oxygen deficiency, high physical 
load. With the help of adaptogenes glycogen responsible for muscles nourishment can accumulate in a heart and in a liver. Adaptogenes influence sensitivity of body cells for harmonic compounds which assist exact regulation of metabolism.

According to folk healers, hypericum with yellow flowers and leaves has a unique range of wound-healing properties. Hypericum-based drugs strengthen the function of mitochondrium which allows to increase muscles force, endurance, body resistance to various illnesses. Hypericum also has an androgenic activity.

Some Siberian folk healers believe that leuzea allows to quickly increase muscles mass, to optimize a lever state, to regulate blood composition, to increase efficiency and to improve heart workload.

Chinese Shisandra is also among very active adaptogenes. It allows some extracts similar to doping means to substantially increase excitation of human nervous system. In folk healing Chinese Shisandra is used to increase acidity of gastric juice, to improve food digestion, to cure apathy and depression.

Under the influence of Chinese Schisandra physical and brain efficiency is increased. Sports doctors recommend todrink Schisandra-based beverages during competitions to mobilize body resources to maximum.

Eleutherococcus is a gingseng match. It improves colour vision, it possesses antitoxic, radiation protective, antihypoxemic and antistress properties. The body thermoregulation is improved due to more intensive oxidation of glucose and fatty acids under the influence of eleutherococcus-based drugs. Eleutherococcus tinctures and extracts offered by drugstores have got a high preventive potential against catarrhal illnesses and colds.

A constant in-take of one type of an adaptogene causes drug habituation and decreases therapeutic effect. As a rule, an adaptogene is taken once a day in the morning in the dosages Table 1: Adaptogenes influence on various types of training loads. recommended by a doctor.

Natural vegetative adaptogenes go very well together with water- and fat-soluble vitamins and pharmaceutical preparations. It is necessary to keep in mind that adaptogenes increase the action of caffeine and ephedrine.

The existing types of valuable components extraction from plants-adaptogenes are not efficient because they are based on ethanol extraction or on hot water infusion. In our opinion it is most expedient to extract adaptogene lipoids from plants by liquid $\mathrm{CO}_{2}\left(\mathrm{CO}_{2}\right.$-extracts) and to extract water soluble substances from $\mathrm{CO}_{2}$-cake by saturated water. Subcritical $\mathrm{CO}_{2}$-extraction of preliminary prepared and cut plants was held in the extraction workshop of LLC "Kampania Karavan" (=LLC "KARAVAN COMPANY"). The starting mixture was prepared in the following ratio: flowers and leaves of hypericum $20 \%$, eleutherococcus roots $30 \%$, leusea roots $20 \%$, berries of Chinese Schisandra $30 \%$. Complex $\mathrm{CO}_{2}$-extract "ZELL" is a fatty fluid adaptogene of light-brown color with a spicy-sharp smell. The sports doctors recommend taking adaptogenes in the morning, as this intake will coincide with a physiological morning wake-up and activation of the body metabolism.

Based on the recommendation of a doctor-dietologist daily morning intake of the adaptogene on the fatty carrier (sour cream, cream) is 10 drops.

From the point of view of pharmocodynamics $\mathrm{CO}_{2}$-mixtures of adaptogenes influence metabolism in an athlete's body and under the conditions of extreme training load they stimulate the process of oxidative phosphorilation.

Table 1 illustrates expediency to use natural adaptogenes under the conditions of various training exercises.

As it follows from Table 1, it is expedient to go in for the adaptogenes during a preparatory stage and during a competition itself.

\begin{tabular}{|c|c|c|c|c|c|}
\hline Stages of Training & Coordination & Speed-Strength & Fights & Endurance \\
\hline Preparatory & + & + & + & + \\
\hline Prior to competition & & + & + & + \\
\hline Basic & + & + & + & + \\
\hline Special preparation & + & + & + & + \\
\hline Competition & + & + & + \\
\hline
\end{tabular}


As one can see from Table 2, the main effect of $\mathrm{CO}_{2}$ adaptagene "ZELL" is physical energy stimulation.

Table 2: Comparison of anthropometric data and muscle force of the sportsmen who has taken the adaptogene during three-weeks' training session.

\begin{tabular}{|c|c|c|c|c|c|c|}
\hline \multirow{3}{*}{$\begin{array}{l}\text { Property of } \\
\text { Interest }\end{array}$} & \multirow{3}{*}{ Initial Data } & \multirow{2}{*}{\multicolumn{2}{|c|}{$\begin{array}{c}\text { Test Group } \\
\text { Period of Observation } \\
\end{array}$}} & \multirow{3}{*}{ Initial } & \multirow{2}{*}{\multicolumn{2}{|c|}{$\begin{array}{c}\text { Experimental Group } \\
\text { Period of Observation }\end{array}$}} \\
\hline & & & & & & \\
\hline & & 1week & 3weeks & & 1week & 3weeks \\
\hline 1 & 2 & 3 & 4 & 5 & 6 & 7 \\
\hline Weight, kgs & 75,5 & $75,6 \pm 2,8$ & $75,5 \pm 2,8$ & $77 \pm 2,1$ & $76,6 \pm 2,9$ & $76,96 \pm 2,91$ \\
\hline Height, sm & 173,0 & $173,3 \pm 2,03$ & $173,0 \pm 2,03$ & $178,6 \pm 2,4$ & $178,3 \pm 2,01$ & $179,0 \pm 2,02$ \\
\hline $\begin{array}{c}\text { Chest } \\
\text { measurement, sm }\end{array}$ & 100,3 & $100,5 \pm 1,05$ & $100,8 \pm 1,06$ & $100,9 \pm 2,1$ & $100,8 \pm 1,09$ & $101,2 \pm 1,1$ \\
\hline Basal blood & $113 / 62$ & $115 \pm 1,77$ & $113 \pm 1,7$ & $113 \pm 1,7$ & $112 \pm 1,8$ & $113 \pm 1,9$ \\
\hline pressure & & $63 \pm 1,2$ & $60 \pm 1,3$ & $60 \pm 1,6$ & $62 \pm 1,5$ & $62 \pm 1,5$ \\
\hline Deadlift & 170 & $170,1 \pm 7,6$ & $170 \pm 7,6$ & $170 \pm 6,5$ & $171,8 \pm 7,81$ & $185 \pm 7,9$ \\
\hline \multirow[t]{2}{*}{$\begin{array}{c}\text { Forearm } \\
\text { measurement, sm }\end{array}$} & $36 / 37$ & $36,2 \pm 1,9$ & $36,3 \pm 1,9$ & $36,9 \pm 2,4$ & $36,4 \pm 2,57$ & $36,9 \pm 2,6$ \\
\hline & & $37 \pm 1,91$ & $38 \pm 1,91$ & $42,1 \pm 2,3$ & $42 \pm 1,08$ & $43 \pm 1,09$ \\
\hline $\begin{array}{c}\text { Thigh } \\
\text { measurement, sm }\end{array}$ & 56,2 & $56,5 \pm 2,8$ & $57,5 \pm 2,9$ & $56,9 \pm 3,4$ & $56,8 \pm 2,8$ & $57 \pm 2,85$ \\
\hline Weight Press & 100,5 & $100,8 \pm 9,61$ & $100,8 \pm 9,6$ & $102 \pm 14,2$ & $108,1 \pm 15,3$ & $113,3 \pm 14,0$ \\
\hline Squatting & 125,0 & $129 \pm 13,2$ & $136,6 \pm 14$ & $127 \pm 16,1$ & $140 \pm 15,9$ & $143 \pm 16,1$ \\
\hline
\end{tabular}

\section{References}

1. Grinchenko VS, Kasjanov GI (2016) Razrabotka produktov pitaniya dlia ludei intensivnogo umstvennogo truda Izvestia vuzov. Pischevaya tekhnologiya 5(6): 31-34.

2. Mazurenko EA, Kasjanov GI (2016) Konstruirovanie produktov pitaniya dlia ludej s povyshennoi phizicheskoi aktivnostju. Pischevaya tekhnologiya 5(6): 48-52.

3. Mazurenko EA, Kasjanov GI, Oljkhovatov EA (2016) Razrabotka produktov pitanija dlia sportsmenov-regbistov. Nauchny zhurnal Kub Gau 123(9).

4. Rostovtsev VL, Safonov LV, Aranson MV (2013) Primenenie kompleksa adaptogenov dlia povysheniya adaptatsii k phizicheskim nagruzkam $\mathrm{v}$ lyzhnykh gonkakh. Uchenye zapiski universiteta 8: 146-152.

5. Nosov AM (2004) Lekarstvennye rasteniya. Eksimo, p. 350.

6. Patent RF (2014) Pharmakologicheskaya kompozitsiya dlia povyshenia adaptatsionnykh vozmozhnostei organizma v usloviyakh phizicheskikh nagruzok/Minzanova S.T. and others.

7. Brower VA (2005) Nutraceutical a day may keep the doctor away. EMBO reports 6(8): 708-711.

8. Petroczi A (2007) Supplement use in sport: is there a potentially dangerous incongruence between rationale and practice. Journal of Occupational Medicine and Toxicology 2: 4-9.

9. Winterstein AP (2001) Herbal Supplements: considerations for the Athletic Trainer/A.P. Journal of Athletic Training 36(4): 425-432.

10. ISSN exercise \& sport nutrition review: research \& recommendations.

11. Gorchakova NA, Gudivok YS, Gunina LM (2010) Pharmakologia sporta. Olimp L-ra, Kiev, Ukraine, p. 640.

12. Kasjanov GI (2016) Preparativnoe $\mathrm{CO}_{2}$-ekstragirovanie komponentov iz rastiteljnogo syrja. Kasjanov GI, Silinskaya SM, Inochkina EV, Zanin DE, vuzov I (Eds.), Pischevaya tekhnologiya 1(349): 42- 46.

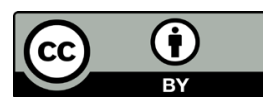

This work is licensed under Creative Commons Attribution 4.0 License

DOI: 10.19080/ARTOAJ.2017.06.555680

\section{Your next submission with Juniper Publishers will reach you the below assets}

- Quality Editorial service

- Swift Peer Review

- Reprints availability

- E-prints Service

- Manuscript Podcast for convenient understanding

- Global attainment for your research

- Manuscript accessibility in different formats

( Pdf, E-pub, Full Text, Audio)

- Unceasing customer service

Track the below URL for one-step submission https://juniperpublishers.com/online-submission.php 